\title{
Synthesis of a New Strigol Analogue from Natural Safrole
}

\author{
Marco Edilson F. de Lima*, André José A. Gabriel and Rosane N. Castro
}

Universidade Federal Rural do Rio de Janeiro, Departamento de Química, ICE, Antiga Rodovia Rio-São Paulo, Km 47, 23.851-970, Seropédica - RJ, Brazil

\begin{abstract}
O alil-benzeno natural safrol, isolado do óleo de Sassafraz (Ocotea pretiosa, Benth) foi utilizado como matéria-prima na síntese de um novo análogo aromático do estrigol que é um potente estimulante de germinação. O novo análogo foi obtido como uma mistura de epímeros em C2' que foram quantificados e separados por cromatografia líquida de alta eficiência.
\end{abstract}

Safrole, isolated from Sassafraz Oil (Ocotea pretiosa, Benth), has been used as starting material in the synthesis of a new strigol analogue which is active as germination stimulant. The new analogue was obtained as a mixture of epimers at C2' which could be separated by high-performance liquid chromatography.

Keywords: strigol analogue, germination stimulant, safrole

\section{Introduction}

Strigol (1, Figure 1) is a highly potent stimulant for the germination of seeds of parasitic weeds belonging to the genera Striga and Orobanche (the application of $10^{-11} \mathrm{~mol}$ $\mathrm{L}^{-1}$ solutions of strigol is reported to result in over $50 \%$ of germination). Strigol was isolated in 1966 by Cook and coworkers ${ }^{1}$ from the root exudates of cotton (Gossypium hirsutum, L.) and its chemical structure was elucidated in $1972 .^{2}$ Considerable effort has been put into the development of strategies for the total synthesis of strigol and for the preparation of new analogues which have a simpler structure but which have retained an apreciable biological activity. Recently, several reports appeared in the literature involving studies on chemical, spectrometric and stereochemical aspects of strigol as well as of its analogues, which evidence the great interest arisen by this substance. ${ }^{3}$

Compounds 2-4 (Figure 1) were synthesized and biologically evaluated by Johnson and co-workers ${ }^{4}$ and the results obtained suggest that the portion of the strigol molecule which is primarily responsible for the bioactivity resides in the CD moiety. Mangnus et al. ${ }^{5}$ have carried out a systematic structure-activity relationship study on strigol analogues and the results obtained suggest that when additional rotational freedom is introduced in the analogues, by opening of ring $\mathrm{C}(\mathbf{5})$ or at a lesser extent by opening ring $\mathrm{B}(\mathbf{6})$, the bioactivity is negatively influenced.

e-mail: marco@ufrrj.br

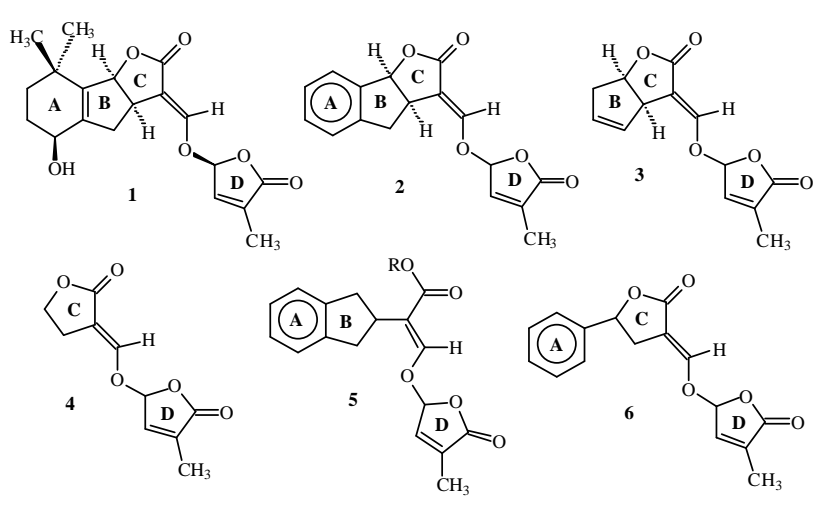

Figure 1. Structures of strigol 1 and synthetic analogues 2-6.

\section{Results and Discussion}

Based on the results presented above, we proposed the synthesis of a new strigol analogue 7 (Scheme 1) using safrole, the natural allylbenzene $\mathbf{1 3}$ (isolated from Ocotea pretiosa Benth $)^{6}$ as starting material. The key step in our synthetic approach is the cyclization reaction of isosafrole 12 (obtained quantitatively from natural safrole by a base mediated isomerization reaction). ${ }^{7}$ This cyclization takes place with concomitant homologation of one carbon atom and was originally reported by Witiak ${ }^{8}$ and modified by Barreiro and Lima ${ }^{7}$ giving the substituted indanone $\mathbf{1 1}$ in $70 \%$ overall yield from 13 (Scheme 1). The alkylated intermediate $\mathbf{1 0}$ was obtained by formation and reaction of the enolate of ketone $\mathbf{1 1}$ with ethyl bromoacetate. Although we $^{9}$ and others ${ }^{10}$ described the use of LDA as a base for enolisation of 11, best results were obtained employng $\mathrm{NaH}$ 
as the base which implies in $70-80 \%$ yield and simpler manipulations. The next step in the planned synthetic route involves the reduction with sodium borohydride ${ }^{11}$ of the sodium salt obtained by hydrolysis of keto-ester $\mathbf{1 0}$, followed by treatment of the reaction mixture with acid $(\mathrm{pH}=2)$, affording lactone 9 in $80 \%$ yield. The benzylic alcohol obtained from $\mathbf{1 0}$ is a mixture of cis and trans isomers, but the only product detected after acidification is $\mathbf{9}$ which arises from usual lactonization of the cis isomer in acidic medium and from trans isomer via the intramolecular displacement of the protonated hydroxyl group by the carboxyl oxygen ${ }^{12}$. Lactone 9 was converted to its potassium enolate by treatment with $t$-BuOK in THF, and formylated using ethyl formate yielding the hydroxymethylene lactone $\mathbf{8}$ in $60 \%$ yield, after acidification of the mixture. Reaction of the potassium salt of $\mathbf{8}$ with bromobutenolide $\mathbf{1 4}$ in tetrahydrofuran afforded the desired product 7 as a mixture of epimers (45:50) at C2', in 50\% yield (Scheme 1). Bromobutenolide 14 was easily prepared though allylic bromination ${ }^{13}$ of the corresponding butenolide wich is commercially available. The $E$ stereochemistry for the enol ether double bond of $\mathbf{7}$ is supported by the presence of signals of proton resonances in the NMR spectrum at $\delta 7.38$ and $7.40 \mathrm{ppm}$. These are essentially the same as those reported for strigol $(\delta 7.42 \mathrm{ppm})^{2}$ and different from those of analogues having $\boldsymbol{Z}$ stereochemistry $(\delta \text { 6.6-6.8ppm })^{13}$.
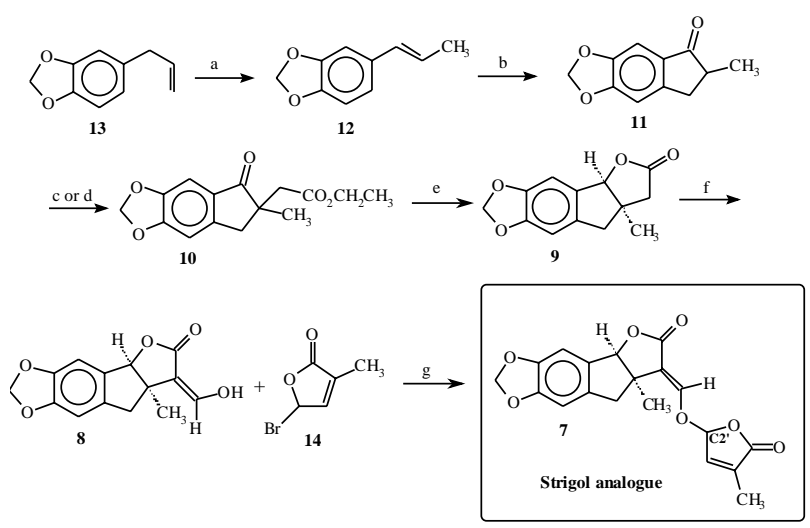

a) $\mathrm{KOH}, n$-butanol, $\Delta, 3 \mathrm{~h}$; b) $\mathrm{POCl}_{3}, \mathrm{DMF}, 0^{\circ} \mathrm{C}$, then $110^{\circ} \mathrm{C}$, isosafrole $12,110^{\circ} \mathrm{C}, 3 \mathrm{~h}$; then $\mathrm{NaOH}$ aq., $12 \mathrm{~h}, 25^{\circ} \mathrm{C}$ c) LDA, THF, $-78^{\circ} \mathrm{C}$, then $\mathrm{BrCH}_{2} \mathrm{CO}_{2} \mathrm{CH}_{2} \mathrm{CH}_{3},-78 \rightarrow 20^{\circ} \mathrm{C}, 8 \mathrm{~h}$; d) $\mathrm{NaH}$, DMF, $60^{\circ} \mathrm{C}, 20 \mathrm{~h}$; then $\mathrm{BrCH}_{2} \mathrm{CO}_{2} \mathrm{CH}_{2} \mathrm{CH}_{3}$ e) $\mathrm{NaOH} / \mathrm{H}_{2} \mathrm{O}, 3 \mathrm{~h}, 25^{\circ} \mathrm{C}$, then $\mathrm{NaBH}_{4}, 65 \mathrm{~h}$; then $\mathrm{HCl}$, overnight f) $t$ - $\mathrm{BuOK}, \mathrm{THF}, 25^{\circ} \mathrm{C}, 1 \mathrm{~h}$, then $\mathrm{HCO}_{2} \mathrm{CH}_{2} \mathrm{CH}_{3}$, one day; g) $t$-BuOK, THF, then bromobutenolide $14,25^{\circ} \mathrm{C}, 2$ days.

Scheme 1. Synthetic route for the new strigol analogue 7.

Although the spectral characteristics of isomers 7 at C2' (Scheme 1) are essentially identical, their retention times in HPLC are different. A method for the quantitation and separation of epimers 7 using normal-phase high performance liquid chromatography was developed. The quantitative determination (45:50) of the isomers was achieved on a silica analytical column using a elution gradient system at room temperature. For complete separation of the diastereoisomers a semi-preparative silica column was used under the same conditions. The relative stereochemistry of two epimers at C2' was not assigned.

\section{Experimental}

The ${ }^{1} \mathrm{H}$ and ${ }^{13} \mathrm{C}$ NMR spectra were recorded on a Bruker AC 200. The IR spectra were obtained with a Perkin-Elmer 1420 spectrometer. The mass spectra were were obtained with a HP-QP-2000A computer system and the high resolution analysis in anAutospec Micromass-EBE-High resolution. The purity of compounds was observed by ${ }^{1} \mathrm{H}$ and ${ }^{13} \mathrm{C}$ NMR spectral analysis by gas chromatography and by TLC (Merck 60F 254) visualised with UV lamp (254 $\mathrm{nm})$. The melting points were obtained with a Büchi-Tottoli apparatus and are uncorrected. The HPLC analysis were carried out on a Shimadzu LC-10 AS Chromatograph, with a SPD-10 A UV detector and the CG analysis with a Varian chromatograph mod. 2400.

\section{3,4-methylenedioxy-propenylbenzene $(\mathbf{1 2})^{7}$}

To $9.1 \mathrm{~mL}$ (10g, $62 \mathrm{mmol})$ of natural allyl benzene $\mathbf{1 3}$ were added $50 \mathrm{~mL}(150 \mathrm{mmol})$ of a $3 \mathrm{~mol} \mathrm{~L}^{-1}$ solution of potassium hydroxide in $n$-butanol and the reaction mixture was stirred under reflux for $3 \mathrm{~h}$. After cooling, the mixture was poured into a solution of $3 \mathrm{~mL}$ of concentrated hydrochloric acid and $20 \mathrm{~mL}$ of ice water. After neutralization the organic layer was washed with water and dried with anydrous $\mathrm{Na}_{2} \mathrm{SO}_{4}$. After removal of the excess $n$-butanol, the residue obtained was distilled under reduced pressure giving $9.5 \mathrm{~g}$ (95\%) of the styrene derivative $\mathbf{1 2}$ as a colorless oil. The spectroscopic data obtained from an analytical sample are identical to those previously reported ${ }^{7}$.

\section{(2-Methyl-5,6-methylenedioxy-1-oxa)-indane (11) ${ }^{7}$}

To $5.2 \mathrm{~mL}(4.9 \mathrm{~g}, 66.6 \mathrm{mmol})$ of dry dimethylformamide $1.2 \mathrm{~mL}(1.97 \mathrm{~g}, 12.9 \mathrm{mmol})$ of $\mathrm{POCl}_{3}$ was added in a dropwise manner with stirring at $0^{\circ} \mathrm{C}$ and under $\mathrm{N}_{2}$ atmosphere. The ice bath was removed and the mixture was stirred for $15 \mathrm{~min}$ at room temperature. The mixture was then stirred in an oil bath at $110-120^{\circ} \mathrm{C}$ when $1.5 \mathrm{~mL}$ of the styrilbenzene $12(1.37 \mathrm{~g}, 9.26 \mathrm{mmol})$ was added dropwise and the reaction mixture was stirred at $110-120^{\circ} \mathrm{C}$ for $3 \mathrm{~h}$. The resulting black mixture was poured into ice water and extracted twice with $10 \mathrm{~mL}$ of diethyl ether. The aqueous layer was basified by addition of a $7 \mathrm{~mol} \mathrm{~L}^{-1}$ aqueous $\mathrm{NaOH}$ solution and stirred over-night at room 
temperature. The reaction mixture was extracted three times with $15 \mathrm{~mL}$ of chloroform. The organic layer was washed with saturated $\mathrm{NaCl}$ solution, dried over $\mathrm{Na}_{2} \mathrm{SO}_{4}$ and concentrated under reduced pressure. The residue obtained was purified by column chromatography [eluent: hexaneethyl acetate (9:1)] giving $1.2 \mathrm{~g}(70 \%)$ of ketone $\mathbf{1 1}$ as an yellow pale solid. mp: $64-65^{\circ} \mathrm{C}$ (lit.: $63-63.5^{\circ} \mathrm{C}$ ). ${ }^{7,8} \mathrm{IR}$ $\mathrm{v}_{\max }\left(\mathrm{cm}^{-1}\right)(\mathrm{KBr}): 1688.8,936.2,853.0$ and 807.0. ${ }^{1} \mathrm{H}$ NMR $\left(\mathrm{CDCl}_{3}, 200 \mathrm{MHz}\right): \delta 6.95(\mathrm{~s}, 1 \mathrm{H}), 6.69(\mathrm{~s}, 1 \mathrm{H}), 5.96$ (s, 2H), 3.24 (dd, 1H, J 16.57, 7.13 Hz), 2.61-2.58 (m, 2H) and $1.18(\mathrm{~d}, 3 \mathrm{H}, J 7.13 \mathrm{~Hz}) .{ }^{13} \mathrm{C} \mathrm{NMR}\left(\mathrm{CDCl}_{3}, 50.3 \mathrm{MHz}\right)$ : $\delta 207.16(\mathrm{C}=\mathrm{O}), 154.01(\mathrm{C}), 150.70(\mathrm{C}), 147.95(\mathrm{C}), 130.45$ (C), $105.33(\mathrm{CH}), 103.75(\mathrm{CH}), 101.95\left(\mathrm{CH}_{2}\right), 42.15(\mathrm{C})$, $34.64\left(\mathrm{CH}_{2}\right), 16.33\left(\mathrm{CH}_{3}\right)$. MS (70 eV): $190\left(\mathrm{M}^{+.} 70 \%\right)$, $175(100 \%), 162$ (8\%), 147 (17\%), 131 (11\%), $103(17 \%)$, $89(7 \%), 77(19 \%), 63(16 \%)$ and $51(17 \%)$.

\section{Ethyl(5,6-methylenedioxy-2-methylindan-2-yl)acetate (10)}

To a suspension of $0.172 \mathrm{~g}(3.57 \mathrm{mmol})$ of $\mathrm{NaH}(50 \%$ in mineral oil) in $10 \mathrm{~mL}$ of $\mathrm{DMF}$ at room temperature was added dropwise a solution of $0.452 \mathrm{~g}(2.37 \mathrm{mmol})$ of ketone 11 with stirring. The resulting mixture was stirred in an oil bath at $65^{\circ} \mathrm{C}$ for $1 \mathrm{~h}$, followed by addition of 0.53 $\mathrm{mL}(0.079 \mathrm{~g}, 4.74 \mathrm{mmol})$ of ethyl bromoacetate. The mixture was stirred at $65^{\circ} \mathrm{C}$ for an additional $1 \mathrm{~h}$ and then poured into $20 \mathrm{~mL}$ of ice water; it was then extracted with diethyl ether $(3 \times 10 \mathrm{~mL})$. The organic layer was washed with saturated $\mathrm{NaCl}$ solution, dried over $\mathrm{Na}_{2} \mathrm{SO}_{4}$ and concentrated under reduced pressure. The residue obtained was purified by flash-chromatography [eluent: hexaneethyl acetate (9:1)] giving $0.38 \mathrm{~g}(70 \%)$ of the keto ester 10 as a viscous yellow oil. IR $v_{\max }\left(\mathrm{cm}^{-1}\right)$ (film): 1729.7, 1701.2, 936.4, 869.9 and 805.6. ${ }^{1} \mathrm{H} \mathrm{NMR}\left(\mathrm{CDCl}_{3}, 200\right.$ $\mathrm{MHz}): \delta 7.01$ (s, 1H), 6.77 (s, 1H), 6.03 (s, 2H), $3.98(\mathrm{q}, 2 \mathrm{H}$, $J 6.9 \mathrm{~Hz}), 3.17(\mathrm{~d}, 1 \mathrm{H}, J 17.0 \mathrm{~Hz}), 2.80(\mathrm{~d}, 1 \mathrm{H}, J 17.0 \mathrm{~Hz})$, 2.75 (d, 1H, J 16.16 Hz), 2.57 (d, 1H, J 16.16 Hz); 1.18 (s, $3 \mathrm{H})$ and $1.10(\mathrm{t}, 3 \mathrm{H}, J 6.9 \mathrm{~Hz}) \cdot{ }^{13} \mathrm{C} \mathrm{NMR}\left(\mathrm{CDCl}_{3}, 50.3\right.$ $\mathrm{MHz}): \delta 207.13(\mathrm{C}=\mathrm{O}), 171.20(\mathrm{C}=\mathrm{O}), 154.34(\mathrm{C}), 149.58$ (C), $148.19(\mathrm{C}), 129.64(\mathrm{C}), 105.67(\mathrm{CH}), 102.77(\mathrm{CH})$, $102.07\left(\mathrm{CH}_{2}\right), 60.36\left(\mathrm{CH}_{2}\right), 47.13(\mathrm{C}), 41.64\left(\mathrm{CH}_{2}\right), 40.10$ $\left(\mathrm{CH}_{2}\right), 24.78\left(\mathrm{CH}_{3}\right)$ and 13,98 $\left(\mathrm{CH}_{3}\right)$. MS (70 eV): 276

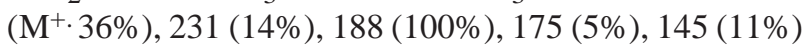
and $115(13 \%)$.

\section{cis-5,6-methylenedioxy-2-methylindan-2-ylaceticacid $\gamma$-lactone(9)}

A solution of $1.62 \mathrm{~g}(6.98 \mathrm{mmol})$ of the keto ester 10 in $24 \mathrm{~mL} 1 \mathrm{~mol} \mathrm{~L}^{-1} \mathrm{NaOH}$ (water/methanol; 1:1) was stirred at room temperature for $3 \mathrm{~h}$. Then $0.36 \mathrm{~g}(9.51 \mathrm{mmol})$ of $\mathrm{NaBH}_{4}$ was added to the mixture and it was stirred for $65 \mathrm{~h}$ at room temperature. The solution was cooled in ice and acidified to $\mathrm{pH} 2$ with the addition of concentrated hydrochloric acid and stirred for additional $8 \mathrm{~h}$. After this time white crystals were deposited and filtered giving $1.39 \mathrm{~g}$ $(80 \%)$ of $\gamma$-lactone 9 in a very pure form. mp: $139-141^{\circ} \mathrm{C}$. IR $v_{\max }\left(\mathrm{cm}^{-1}\right)(\mathrm{KBr}): 1761.6,942.2,880.6$ and $852.8 .{ }^{1} \mathrm{H}$ NMR $\left(\mathrm{CDCl}_{3}, 200 \mathrm{MHz}\right): \delta 6.82(\mathrm{~s}, 1 \mathrm{H}), 6.62(\mathrm{~s}, 1 \mathrm{H}), 5.94$ (m, 2H), 5.28 (s, 1H); 2.99 (d, 1H, J 16.07 Hz), 2.84 (d, 1H, $J 16.07 \mathrm{~Hz}), 2.63$ (d, H, $J 17.73 \mathrm{~Hz}), 2.52$ (d, H, $J 17.73 \mathrm{~Hz})$ and $1,38(\mathrm{~s}, 3 \mathrm{H}) .{ }^{13} \mathrm{C} \mathrm{NMR}\left(\mathrm{CDCl}_{3}, 50.3 \mathrm{MHz}\right): \delta 176.26$ (C=O), 149.34 (C), 147.36 (C), 135.84 (C), 131.09 (C), $105.95(\mathrm{CH}), 105.14(\mathrm{CH}), 101.31\left(\mathrm{CH}_{2}\right), 92.78(\mathrm{CH}), 46.55$ (C), $44.22\left(\mathrm{CH}_{2}\right), 42.48\left(\mathrm{CH}_{2}\right)$ and $24.59\left(\mathrm{CH}_{3}\right)$. MS (70 $\mathrm{eV})$ : $232\left(\mathrm{M}^{+} .47 \%\right) ; 203$ (3\%); 188 (16\%); 173 (100\%); $143(19 \%)$ and $129(11 \%)$.

\section{Preparation of 7}

To a stirred solution of $0.35 \mathrm{~g}(3.02 \mathrm{mmol})$ of potassium tert-butoxide in $7 \mathrm{~mL}$ of dry $\mathrm{THF}$ at $0^{\circ} \mathrm{C}$ under argon atmosphere was added dropwise a solution of $0.50 \mathrm{~g}(2.16$ $\mathrm{mmol}$ ) of $\gamma$-lactone 9 in $5 \mathrm{~mL}$ of dry THF. The mixture was stirred for $30 \mathrm{~min}$ at $0^{\circ} \mathrm{C}$ when $0.3 \mathrm{~mL}(0.275 \mathrm{~g}, 3.6 \mathrm{mmol})$ of ethyl formate was added. After $48 \mathrm{~h}$, the reaction mixture was evaporated under reduced pressure and $20 \mathrm{~mL}$ of iced dichloromethane was added to the residue. This was filtered and washed with iced dichloromethane $(2 \times 5 \mathrm{~mL})$ giving $0.307 \mathrm{~g}(65 \%)$ of the enol intermediate $\mathbf{8}$ as a white solid. This product was used directly in the next step without further purification (mp: $172-174^{\circ} \mathrm{C}$ ).

To a stirred solution of $0.307 \mathrm{~g}(0.17 \mathrm{mmol})$ of hydroxymethylene lactone 8 and $0.184 \mathrm{~g}(1.63 \mathrm{mmol})$ of potassium tert-butoxide in $15 \mathrm{~mL}$ of dry THF under argon atmosphere was added $0.29 \mathrm{~g}(1.63 \mathrm{mmol})$ of bromobutenolide $14^{11}$ and the reaction mixture was stirred for $48 \mathrm{~h}$ at room temperature. Then the mixture was poured into $25 \mathrm{~mL}$ of water and extracted with dichloromethane (3 x $10 \mathrm{~mL})$. The combined organic layers were washed with saturated $\mathrm{NaCl}$ solution, dried over $\mathrm{Na}_{2} \mathrm{SO}_{4}$ and concentrated under reduced pressure. The residue obtained was filtered on a silica gel column (eluent: dichlorometane) giving $0.153 \mathrm{~g}$ (50\%) of a mixture of epimers of 7 as a white solid. mp: 200$220^{\circ} \mathrm{C}$. Exact mass: 356.0896 (calculated); 356.08955 (found). IR $v_{\max }\left(\mathrm{cm}^{-1}\right)(\mathrm{KBr}): 1783.5,1747.0,1675.5$ and 957.0. MS (70 eV): $356\left(\mathrm{M}^{+} .34 \%\right), 297$ (1\%), 259 (15\%), 213 (41\%), 187 (24\%), $129(9 \%)$ and 97 (100\%).

The mixture of diastereoisomers 7 (epimers at C2'; Scheme 1) was separated (7a and 7b) using normalphase high-performance liquid chromatography (HPLC). Prior to the HPLC analysis, the crude isomers were preliminarly purified by flash chromatography on silica gel using $\mathrm{CH}_{2} \mathrm{Cl}_{2}$. A model LC-10AS high-performance liquid chromatograph (Shimadzu, Japan) was used with 
a Rheodyne-7125 injector system and a model SPD-10A UV-VIS detector set at $298 \mathrm{~nm}$. An analytical silica column ( 250 x $4.6 \mathrm{~mm}$ i.d. x $5 \mu \mathrm{m}$, Alltech Co.) and a semipreparative column $(250$ x $10 \mathrm{~mm}$ i.d. x $5 \mu \mathrm{m}$, Alltech Co.) were used for analysis and separation. The chromatograms and integration data were recorded with a CR-6A integrator (Shimadzu, Japan). The samples were dissolved in ethyl acetate and 10 $\mu \mathrm{L}$ aliquots were injected for HPLC analysis. The analytical separation in a non-overload condition used gradient elution system at a flow-rate of $1.1 \mathrm{~mL} \mathrm{~min}^{-1}$; in a semipreparative mode in a column-overload condition the flowrate was $6.0 \mathrm{~mL} \mathrm{~min}{ }^{-1}$. The gradient elution program was set at $1.1 \mathrm{~mL} \mathrm{~min}^{-1}$, starting with a $n$-hexane-ethyl acetate mixture $(65 \% \mathrm{v} / \mathrm{v})$ for $15 \mathrm{~min}$. The program proceeded to $n$ hexane-ethyl acetate $(75 \% \mathrm{v} / \mathrm{v})$ with the same flow-rate for $15 \mathrm{~min}$ and then returned to initial conditions. The infrared and mass spectra of two isomers (7a and $7 \mathbf{b})$ were virtually superimposable and this was run for the mixture.

Diastereoisomer 7a (retention time: $21.7 \mathrm{~min}$ ): $\mathrm{mp}$ : 214-215 ${ }^{\circ} \mathrm{C} .{ }^{1} \mathrm{H} \mathrm{NMR}\left(\mathrm{CDCl}_{3}, 200 \mathrm{MHz}\right): \delta 7.40$ (s, $\left.1 \mathrm{H}\right)$, 6.95-6.93 (m, 1H), $6.79(\mathrm{~s}, 1 \mathrm{H}), 6.55(\mathrm{~s}, 1 \mathrm{H}), 6.15(\mathrm{~s}, 1 \mathrm{H})$, 5.92-5.91 (m, 2H), $5.32(\mathrm{~s}, 1 \mathrm{H}), 3.27$ (d, 1H, J 16 Hz), 2.90 $(\mathrm{d}, 1 \mathrm{H}, J 16 \mathrm{~Hz}), 2.01(\mathrm{~d}, 3 \mathrm{H}, J 1.48 \mathrm{~Hz})$ and $1.49(\mathrm{~s}, 3 \mathrm{H})$. ${ }^{13} \mathrm{C} \mathrm{RMN}\left(\mathrm{CDCl}_{3}, 50.3 \mathrm{MHz}\right)$ : d $171.208(\mathrm{C}=\mathrm{O}), 170.202$ $(\mathrm{C}=\mathrm{O}), 151,11(\mathrm{C}=), 149.59(\mathrm{C}), 147.50(\mathrm{C}), 140.98(\mathrm{C}=)$, $135.99(\mathrm{C}=), 135.91(\mathrm{C}), 131.15(\mathrm{C}), 117.42(\mathrm{C}=), 105.71$ $(\mathrm{CH}), 104.77(\mathrm{CH}), 101.40(\mathrm{CH}), 100.73\left(\mathrm{CH}_{2}\right), 92.20(\mathrm{CH})$, $48.26(\mathrm{C}), 44.07\left(\mathrm{CH}_{2}\right), 23.92\left(\mathrm{CH}_{3}\right)$ and $10.72\left(\mathrm{CH}_{3}\right)$.

Diastereoisomer $\mathbf{7 b}$ (retention time: $24.9 \mathrm{~min}$ ): $\mathrm{mp}$ : 226-227 ${ }^{\circ} \mathrm{C} .{ }^{1} \mathrm{H} \mathrm{NMR}\left(\mathrm{CDCl}_{3}, 200 \mathrm{MHz}\right): \delta 7.38(\mathrm{~s}, 1 \mathrm{H})$, 6.95-6.93 (m, 1H), $6.83(\mathrm{~s}, 1 \mathrm{H}), 6.57(\mathrm{~s}, 1 \mathrm{H}), 6.12(\mathrm{~m}, 1 \mathrm{H})$, 5.95-5.93 (m, 2H), $5.34(\mathrm{~s}, 1 \mathrm{H}), 3.30(\mathrm{~d}, 1 \mathrm{H}, J 16.54 \mathrm{~Hz})$, $2.94(\mathrm{~d}, 1 \mathrm{H}, J 16.51 \mathrm{~Hz}), 2.03(\mathrm{~d}, 3 \mathrm{H}, J 1.56 \mathrm{~Hz})$ and $1.49(\mathrm{~s}$, $3 \mathrm{H}) .{ }^{13} \mathrm{C} \mathrm{NMR}\left(\mathrm{CDCl}_{3}, 50,3 \mathrm{MHz}\right): \delta 171.22(\mathrm{C}=\mathrm{O}), 170.20$ $(\mathrm{C}=\mathrm{O}), 150.92(\mathrm{C}=), 149.65(\mathrm{C}), 147.58(\mathrm{C}), 140.85(\mathrm{C}=)$, $136.08(\mathrm{C}=), 135.94(\mathrm{C}), 131.36(\mathrm{C}), 117.49(\mathrm{C}=), 105.89$ $(\mathrm{CH}), 104.71(\mathrm{CH}), 101.47(\mathrm{CH}), 100.64\left(\mathrm{CH}_{2}\right), 92.19(\mathrm{CH})$, $48.39(\mathrm{C}), 43.98\left(\mathrm{CH}_{2}\right), 23.93\left(\mathrm{CH}_{3}\right)$ and $10.81\left(\mathrm{CH}_{3}\right)$.

\section{Conclusion}

The results obtained demonstrate the feasibility of employing natural products as starting materials in the synthesis of biologically active molecules. The new analogue 7 will be submitted to biological assays in order to investigate its potential activity as germination stimulant. Preliminary results obtained were very promising ${ }^{14}$.

\section{Acknowledgement.}

We thank Instituto de Química, Unicamp for ${ }^{1} \mathrm{H}-\mathrm{RMN}$ spectrum of the final product and Prof. V. Rumjanek (DequimUFRRJ) for reading the manuscript. Financial support from Capes to A. Gabriel and CNPq (grant \#520546/95) are gratefully acknowledged.

\section{References}

1. Cook, C. E.; Whichard, L. P.; Turner, B.; Wall, M. E.; Egley, G. H. Science 1966, 154, 1189.

2. Cook, C. E.; Whichard, L. P.; Wall, M. E.; Egley, G. H.; Coggon, P.; Luhan, P. A.; McPhail, A. T. J. Am. Chem. Soc. 1972, 94, 6198.

3. (a) Mangnus, E. M.; Zwanenburg, B. J. Agric. Food Chem. 1992, 40, 697. (b) Frischmuth, K.; Wagner, U.; Samson, E.; Weigelt, D.; Koll, P.; Meuer, H.; Sheldrick, W. S.; Welzel, P. Tetrahedron Assymm. 1993, 4, 351. (c) Frischmuth, K.; Muller, D.; Welzel, P. Tetrahedron 1998, 54, 3401. (d) Röhrig, S.; Henning, L.; Findeisen, M.; Welzel, P.; Frischmuth, K.; Marx, A.; Petrowitsh, T.; Koll, P.; Müller, D.; Mayer-Figge, H.; Sheldrick, W.S. Tetrahedron 1998, 54, 3413. (e) Röchrig, S.; Henning, L.; Findeisen, M.; Welzel, P.; Muller, D. Tetrahedron 1998, 54, 3439.

4. (a) Johnson, A.W.; Roseberrry, G. Parker, C. Weed Res. 1976, 16, 223. (b) Johnson, A.W.; Gowda, G.; Hassanali, A.; Knox, J.; Monaco, S.; Razavi, Z.; Rosebery. G. J. Chem. Soc., Perkin Trans. I 1981, 1734.

5. Mangnus, E. M.; van Vliet, L.A.; Vandenput, D. A. L.; Zwanenburg, B. J. Agric. Food Chem. 1992, 40, 1222.

6. Mors, W. B.; Rizzini, C. T. Botânica Econômica, Epu, São Paulo-Brazil, 1976, p.149.

7. Barreiro, E. J.; Lima, M. E. F. J. Pharm. Sci.1992, 12, 1219.

8. Witiak, D. T.; Willians, D. R.; Kakodkar, S. V. J. J. Org. Chem. 1974, 39, 1242.

9. Lima, M. E. F.; Gabriel, A. J. A. Abstracts from $8^{\text {th }}$ Brazilian Meeting on Organic Synthesis, São Pedro, SP, Brazil, 1998.

10. César, M. A. F. M. Sci. Thesis, Instituto de Química, UFRJ, 1991.

11. Kendall, P. M.; Johnson, J. V.; Cook, C. E. J. Org. Chem. 1979, 44, 1421.

12. Kádas, I.; Árvai, G.; Töke, L.; Tóth, G.; Szöllösy, A.; Bihari, M. Tetrahedron 1994, 50, 2895.

13. (a) MacAlpine, G. A.; Raphael, R.A.; Shaw, A.; Taylor, A. W.; Wild, H. -J. J. Chem. Soc, Chem. Commun. 1974, 834. (b) MacAlpine, G.A.; Raphael, R.A.; Shaw, A.; Taylor, A. W.; Wild, H. -J. J. Chem. Soc, Perkin Trans. I 1976, 410.

14. Gabriel, A. J. A.; Silva, O. F. C.; Sampaio, F.; Souza, S. R.; Lima, M. E. F. Abstracts from $22^{\text {nd }}$ Annual Meeting of the Brazilian Chemical Society, Poços de Caldas, MG, Brazil, 1999. 